Jurnal

Manajemen Kesehatan Indonesia

Volume 8

Nomor 2

Agustus 2020

\title{
Analisis Faktor Determinan Stunting di Desa Pesa Kecamatan Wawo Kabupaten Bima
}

\author{
*Rostinah Suherman, *Nurhaidah \\ *Akademi Kebidanan Harapan Bunda Bima \\ Email:rostinahsuherman@gmail.com
}

\begin{abstract}
Indonesia is ranked $5^{\text {th }}$ in the world with the highest number of stunting children. Result of the Basic Health Survey On 2018, the prevalence of children under 5 years old weight was 19,6\% and stunting 37,2\%. Based on the previous obsercation, children with stunting on elementary school children in Bima was 40\%. This research aimed to analyze the main factors which caused stunting in Pesa Village, Wawo Sub-District, Bima District. Data collected using questionnaires and observation to identify factors which cause stunting, such as nutrition status, personal hygene, food safety, environment sanitation, and infectious diseases. Data analyzed using chi aquare and logistic regression test. Result showed that 55,9\% children were categorized as stunting. Nutrition, infectious diseases, hygiene, food safety were the factors which have significant correlation with stunting $(\rho<0,05)$. Factor which the most dominant were food safety $(P O R=37,242)$. The risk of poor food safety or food feeding has 37 times the risk of children suffering with stunting when compared to the children with good food safety.
\end{abstract}

Keywords : Stunting, Risk Factor, children

\section{PENDAHULUAN}

Negara Indonesia menempati peringkat ke 5 dunia dengan jumlah anak pendek terbanyak. Secara global, satu dari empat anak (25\%) di bawah usia lima tahun mengalami keterlambatan perkembangan dan pertumbuhan (Stunting). Hasil dari South East Asian Nutrition Survey (SEANUTS) pada tahun 2010-2011 menempatkan Indonesia sebagai negara yang memiliki jumlah anak balita pendek terbesar. Pada tahun 2010, gambaran tinggi standar anak usia 5 tahun adalah 110 centimeter, namun tinggi rata-rata anak Indonesia umur 5 tahun, kurang dari 6,7 centimeter untuk anak laki-laki dan kurang dari 7,3 centimeter untuk anak perempuan. Kejadian gagal tumbuh yang terjadi pada usia balita akan berlanjut ke usia berikutnya. Besar kemungkinan ketika mereka menginjak usia 19 tahun, maka tinggi badan optimal tidak tercapai. Mereka akan menjadi manusia dewasa yang pendek dengan keterbatasan untuk berproduktivitas optimal. Data menunjukkan masih tingginya persentase perempuan usia 15-19 tahun yang tidak lagi meneruskan sekolah dan masuk pada usia reproduksi yang selanjutnya 
melahirkan lagi anak-anak yang kurang gizi yang berpotensi menjadi Stunting atau anak pendek. Tinggi badan merupakan sifat dasar manusia, di beberapa negara tinggi badan dikaitkan dengan tingkat pendidikan, penghasilan dan posisi sosial yang baik. ${ }^{1-2}$

Stunting pada anak sekolah berhubungan dengan keterlambatan perkembangan motorik, kognitif, dan sosioemotional dan tingginya angka kematian balita. Tinggi badan dikaitkan dengan umur yang panjang, risiko kehamilan, kardiovaskuler, dan pernafasan yang rendah serta mengurangi resiko kanker tertentu. Stunting mengarah untuk efek merusak pada kesehatan jangka pendek dan jangka panjang anak, termasuk peningkatan kerentanan terhadap infeksi dan gangguan perkembangan otak. ${ }^{3-12}$

Hasil Riskesdas Tahun 2018, prevalensi berat badan anak umur dibawah 5 Tahun sebesar 19,6\% dan Stunting 37,2\%. ${ }^{13}$ Banyak faktor yang menyebabkan Stunting yaitu sanitasi, hygene, jajanan sehat serta laporan dari WHO menyatakan bahwa ada hubungan antara antara anak-anak yang tinggal dilingkungan yang mempunyai akses pelayanan kesehatan kurang memadai, lingkungan yang miskin, nutrisi kurang dan keamanan pangan dengan pertumbuhan dan perkembangan anak sekolah[12]. Masalah kesehatan masyarakat dianggap berat bila prevalensi pendek sebesar 30 - 39 persen dan serius bila prevalensi pendek $=40$ persen. Sebanyak 14 provinsi termasuk kategori berat, dan sebanyak 15 provinsi termasuk kategori serius, salah satunya adalah Provinsi Nusa Tenggara Barat.

\section{METODE PENELITIAN}

Penelitian kuantitatif ini mennggunakan pendekatan cross sectional. Waktu Penelitian dilaksanakan selama 3 bulan mulai bulan Maret sampai bulan Mei 2019. Lokasi Penelitian dilaksanakan di Desa Pesa Kecamatan Wawo Kabupaten
Bima Tahun 2019. Populasi pada penelitian ini adalah seluruh balita di Desa Pesa Kecamatan Wawo Kabupaten Bima sejumlah 143. Status gizi dinilai berdasarkan rekomendasi WHO yang menggunakan skor underweight (weight-forage- yaitu (WAZ) $<-2$ SD), pengerdilan (tinggi-untuk-usia $Z$-skor $\quad(\mathrm{HAZ})<-2 \mathrm{SD}$ ), dan ketipisan (indeks massa tubuh rendah(BMI-) untuk usia <-2 SD overweigh (BMIuntuk-usia $\geq$ 2SD)). Penilaian sanitasi/hygene, dan keamanan pangan atau pola makan, penyakit infeksi menggunakan kuesioner standar WHO yang diuji validitas dan realibilitas pada anak usia sekolah yang dilakukan di Kota Bima. Analisi data yang dilakukan meliputi analisis univariat karakteristik responden. Analisis bivariat digunakan uji chi-square. Penelitian ini menggunakan analisis uji chi square dengan Cl 95\% dan $\alpha=0,05$.

Analisis multivariat digunakan untuk melihat faktor yang paling berpengaruh terhadap kejadian stunting pada balita dengan menggunakan regresi logistik dengan pemodelan prediksi. Analisis multivariat dilakukan dengan dimulai dari uji chi square. Faktor risiko dengan p value $<0,25$ dimasukkan dalam pemodelan multivariat dengan analisis regresi logistik ganda.

\section{HASIL DAN PEMBAHASAN}

Stunting adalah kondisi gagal tumbuh sehingga anak terlalu pendek untuk usianya. Atau anak dengan nilai z-scorenya kurang dari -2SD/standar deviasi (stunted) dan kurang dari - 3SD (severely stunted).Dampak Stunting dapat berakibat meningkatnya pengeluaran pemerintah, terutama jaminan kesehatan nasional, ketika dewasa, anak yang mengalami Stunting rentan terhadap serangan penyakit tidak menular seperti jantung, stroke, diabetes, ataupun gagal ginjal, ancaman pengurangan tingkat intelejensi sebesar 5-11 poin, 
sehingga hal ini pun menjadi ancaman masyarakat di Indonesia. Dampak jangka pendek Stunting adalah terganggunya perkembangan otak, kecerdasan, gangguan pertumbuhan fisik, dan gangguan metabolisme dalam tubuh. Dampak jangka panjang adalah akibat buruk yang dapat ditimbulkan adalah menurunnya kemampuan kognitif dan prestasi belajar, menurunnya kekebalan tubuh sehingga mudah sakit, dan resiko tinggi untuk munculnya penyakit diabetes, kegemukan, penyakit jantung dan pembuluh darah, kanker, stroke, dan disabilitas pada usia tua serta menimbulkan pendek lintas generasi. ${ }^{14}$

Stunting disebabkan oleh faktor multi dimensi dan tidak hanya disebabkan oleh faktor gizi buruk yang dialami oleh ibu hamil maupun anak balita. Intervensi yang paling menentukan untuk dapat mengurangi pervalensi Stunting oleh karenanya perlu dilakukan pada 1.000 Hari Pertama Kehidupan (HPK) atau deteksi dini Stunting dari bayi sampai usia balita sehingga efek nya tidak mempengaruhi pertumbuhan dan perkembangan anak usia sekolah. Anakanak yang mengalami hambatan dalam pertumbuhan disebabkan kurangnya asupan makanan yang memadai dan penyakit infeksi yang berulang, dan meningkatnya kebutuhan metabolik serta mengurangi nafsu makan, sehingga meningkatnya kekurangan gizi pada anak. Keadaan ini semakin mempersulit untuk mengatasi gangguan pertumbuhan yang akhirnya berpeluang terjadinya Stunting.

Menurut WHO, Stunting diklasifikasikan jika nilai $\mathrm{Z}$ tinggi badan untuk usia di lebih dari -2. Balita yang menderita stunting berdampak jangka panjang pada perkembangan kognitif, Prestasi sekolah, produktivitas ekonomi di masa dewasa danreproduksi ibu7. Stunting timbul sebagai akibat dari kekurangan gizi kronis terhadap anak. Potensi pertumbuhan terganggu disebabkan oleh efek kronis asupan makanan yang tidak memadai dan kondisi kesehatan yang buruk. ${ }^{15}$

Tabel 1 Hubungan Penyakit Infeksi, Status Gizi, Hygiene/Sanitasi, Keamanan Pola Makan atau Pemberian Makan Dengan Kejadian Stunting Di Pesa Kabupaten Bima

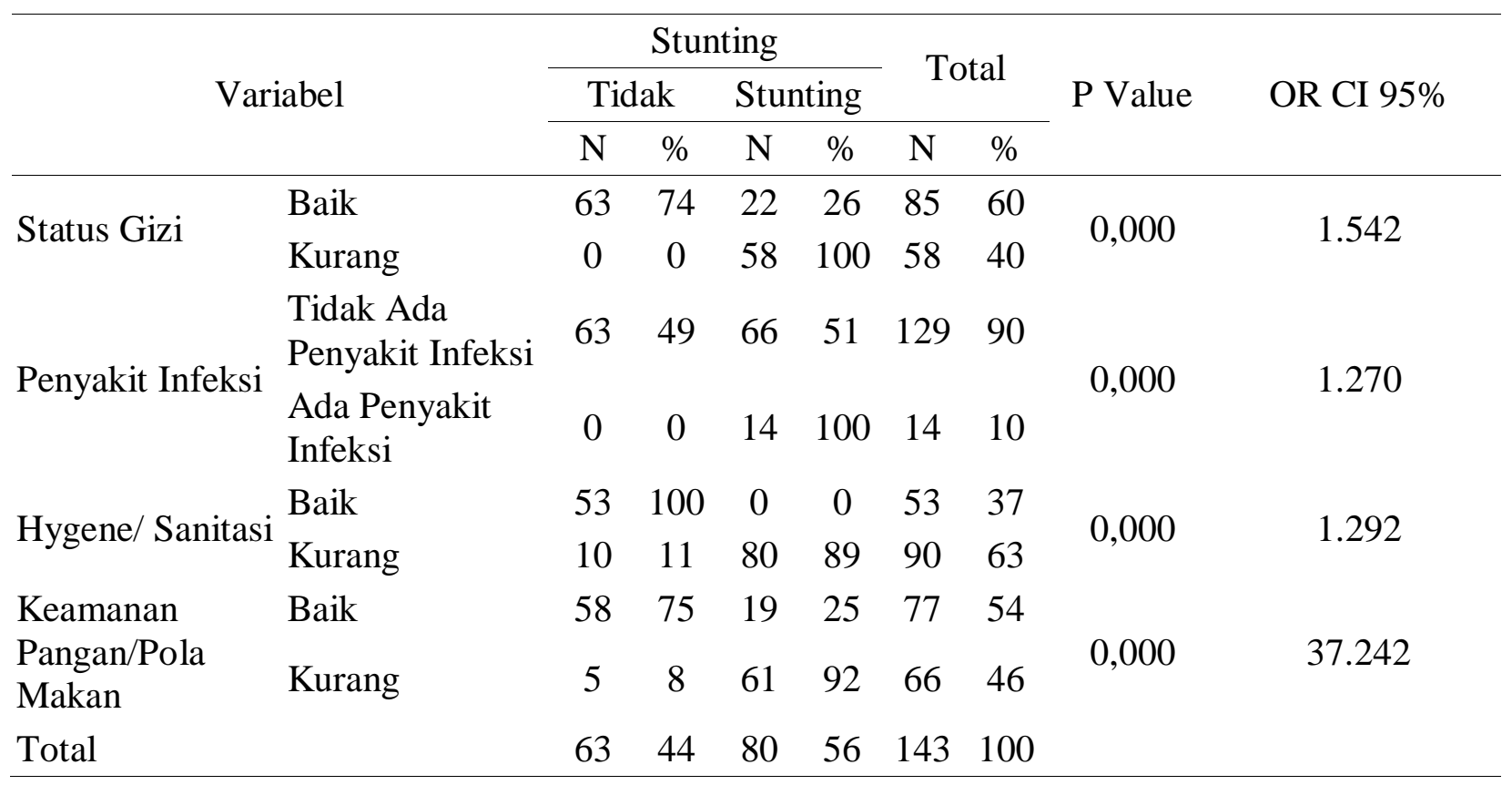


Berdasarkan Tabel 1 didapatkan bahwa $44 \%$ adalah normal, sedangkan $56 \%$ berada pada kondisi stunting (pendek). Hasil analisis antarakondisi penyakit infeksi, status gizi, hygiene/sanitasi, keamanan pangan atau pemberian di Desa Pesa
Kecamatan Wawo Kabupaten Bima dapat dilihat bahwa: Hasil uji statistic chi square menunjukkan semua variabel berhubungan signifikan dengan kejadian stunting $(\rho>0,05)$.

Tabel 2 Pemodelan Faktor - Faktor Yang Berhubungan Dengan Kejadian StuntingPada Balita Di Desa Pesa Kecamatan Wawo kabupaten Bima

\begin{tabular}{lcrccc}
\hline \multicolumn{1}{c}{ Variabel } & B & SE & P & POR*Adj & \multicolumn{1}{c}{ IK 95\% } \\
Status Gizi & -22.255 & 5.275 & 0.997 & 0,000 & $0,000-0.000$ \\
Penyakit Infeksi & -21.156 & 1.074 & 0,998 & 0,000 & $0,000-0.000$ \\
Hygene/Sanitasi & -23.282 & 5.521 & 0.997 & 0.000 & $0,000-0.000$ \\
Keamanan & -3.617 & 0.535 & 0.000 & 0,279 & $0.009-0.077$ \\
Pangan/Pola Makan & -18.524 & 4.710 & 0.997 & 0,000 & \\
Konstanta & & & & & \\
\hline
\end{tabular}

Berdasarkan tabel 2 menunjukkan bahwa variabel status gizi, penyakit infeksi, hygene/sanitasi, penghasilan merupakan varibel yang tidak signifikan dari pemodelan, sehingga dihilangkan dari pemodelankarenadapat merubah nilai OR $>10 \%$ dari pemodelan awal, sehingga penghasilan merupakan faktor confounding padapemodelan ini. Hasil analisis multivariatedidapatkan bahwa keamanan pangan atau pola pemberian makan merupakan faktor yang paling berpengaruh terhadap kejadian stunting pada balita. Berdasarkan hasil uji statistik didapatkan nilai OR 0,279 (95\% CI 0,009-0,077) hal ini berarti bahwa keamanan pangan ataupemberian makan yang tidak baik akan berisiko 2,0 kali pada balita menderita stunting bila dibandingkan dengan balita yang orang tuanya memiliki pola pemberian makan baik atau keamanan pangan baik.

Faktor risiko utama untuk stunting pada penelitian ini adalah penyakit infeksi, status gizi, keamanan pangan atau pola pemberian makan dan sanitasi/hygene. Semua variabel berhubungan signifikan pada penelitian ini. Pada penelitian di
Tanzania tahun 2015 faktor stunting dipengaruhi oleh: usia anak, jenis kelamin anak, Tingkat pendidikan ibu, usia ibu saat kelahiran anak, tempat melahirkan, jenis persalinan, IMT ibu dan riwayat menyusui, ekonomi, sumber air minumdan wilayah geografis8. Hasil analisis hubungan antara kondisi infeksi dengan stunting balita di Kabupaten Pesawaran, diperoleh bahwa riwayat infeksi tidak meningkatkan kejadian stunting. Hasil penelitian ini tidak sejalan dengan penelitian Kusumawati tahun 2015 yang menjelaskan bahwa faktor anak yaitu batita yang sering sakit infeksi akan berisiko 8,84 kali untuk menderita stunting. ${ }^{16}$

Kondisi infeksi berhubungan secara bermakna dengan kejadian stunting.Hasil penelitian ini memang tidak sesuai dengan teori yang sebenarnya yang menjelaskan hubungan infeksi dengan kejadian stunting. Hal ini dapat dijelaskan bahwa penyakit infeksi yang ditanyakan pada kuesioner ini merupakan penyakit infeksi selama satu bulan terakhir yang merupakan infeksi akut. Pada kasus infeksi akut akan berpengaruh kepada berat badan bukan kepada tinggi badan. Oleh sebab itu hal ini yang 
menyebabkan riwayat infeksi tidak berhubungan dengan status gizi dalam kasus stunting. Stunting sendiri merupakan efek jangka panjang dari konsumsi kronis diet yang dikombinasikan dengan morbiditas, penyakit infeksi dan kondisi lingkungan. ${ }^{17}$

Hasil analisis hubungan antara hygiene/sanitasi akan meningkatkan kejadian stunting. Temuan studi ini menunjukkan bahwa balita dari keluarga yang memiliki sumber air minum tidak terlindung lebih banyak mengalami stunting dibandingkan balita dari keluarga yang memiliki sumber air minum terlindung. Studi membuktikan bahwa terdapat hubungan antara sumber air minum dengan kejadian stunting balita. Balita yang ber-asal dari keluarga yang memiliki sumber air minum tidak terlindung 1.35 kali lebih berisiko mengalami stunting dibandingkan dengan balita dari keluarga dengan sumber air minum terlindung. Beberapa penelitian di berbagai negara menunjukkan bahwa kualitas sumber air minum memiliki hubungan positif dengan pengurangan kejadian diare dan kematian pada anak. ${ }^{187}$

Hasil analisis hubungan antara pola asuh dengan status gizi balita di Kabupaten Pesawaran diperoleh bahwa orang tua yang memilik pola asuh tidak mendukung akan meningkatkan kejadian balita stunting sebesar 12,1 kali dibandingkan dengan orang tua dengan pola asuh yang mendukung. Hasil analisis hubungan antara pola pemberian makandengan status gizi balitadi Kabupaten Pesawaran diperoleh bahwa pola pemberian makan tidak baik akan meningkatkan kejadian balita stunting sebesar 15,9 kali dibandingkan dengan orang tua yang melakukan pola pemberianmakan baik Makanan yang mengandung protein berguna untuk pertumbuhan bagi bayisehingga apabila terjadi defisiensi yangkronis dapat menghambat pertumbuhan bagi bayi. ${ }^{16}$
Tidak cukupnya pemberian makanan dan perawatan tambahan Anak untuk mempertahankan nutrisi yang cukup untuk pertumbuhan. Alasannya mungkin anakanak secara bertahap mengadopsi makanan tambahan setelah empat tahun. Perbedaan ini mungkin disebabkan oleh sosial budaya dan variasi makan antara wilayah Somalia dan tempat belajar. ${ }^{17}$

Stunting merupakan refleksi jangka panjang dari kualitas dan kuantitasmakanan yang tidak memadai dan seringmenderita infeksi selama masa kanak-kanak. Anak yang stunting merupakan hasil dari masalah gizi kronis sebagai akibat dari makanan yang tidak berkualitas, ditambah dengan morbiditas, penyakit infeksi, dan masalah lingkungan. ${ }^{16}$

Efek malnutrisi pada proses kognitif juga dilihat dalam kaitannya dengan penurunan nilai tanpa mempengaruhi tingkat perkembangan dan pengaruhnya terhadap laju perkembangan proses kognitif itu sendiri. Para peserta diidentifikasi kekurangan gizi atau diberi gizi cukup dalam kelompok usia lima sampai tujuh tahun dan anak berusia delapan sampai sepuluh tahun. ${ }^{16}$

Dari pelbagai penelitian tentang stunting dan literature yang ada diketahui bahwa selain infeksi stunting berhubungan juga dengan defisiensi gizi (mikronutrien dan makronutrien). Terdapat beberapa zat gizi yang berkaitan dengan stunting seperti protein, zat besi, zink, kalsium, dan vitamin D, A dan C. Selain itu, faktor hormon, genetik dan rendahnya pengetahuan orangtua dalam pengasuhan, kemiskinan, rendahnya sanitasi lingkungan, rendahnya aksesibilitas pangan pada tingkat keluarga terutama pada keluarga miskin, rendahnya akses keluarga terhadap pelayanan kesehatan dasar, dan masih terjadi disparitas antar provinsi yang perlu mendapat penanganan masalah yang sifatnya spesifik di wilayah rawan. Stunting merupakan 
indikator yang sensitif untuk sosial ekonomi yang buruk dan prediktor untuk morbiditas serta mortilitas jangka panjang. ${ }^{16}$

Salah satu upaya pencegahan kejadian stunting adalah dengan meningkatkan peran aktif ibu dalam kegiatan Posyandu di wilayahnya. Pemeriksaan status gizi berkala dapat mencegah kejadian gangguan gizi kronis yang berdampak pada masa depan anak. Pada penelitian Nasri tahun 2016 menjelaskan bahwa Posyandu memberikan dampak positif terhadap pada balita dan meningkatkan pengetahuan ibu tentang gizi balita. Pemantauan 1000 hari kehidupan merupakan cara yang paling ampuh untuk memutus mata rantai stunting.

\section{KESIMPULAN}

Penelitian ini menunjukkan faktor yang berhubungan empat faktor yang secara bersama-sama mempengaruhi stunting (pendek) di Desa Pesa Kabupaten Wawo yaitu Faktor gizi, penyakit infeksi, hygene/sanitasi, keamanan pangan atau pemberian makan. Faktor yang paling dominan adalah keamanan pangan atau pemberian makan $(\mathrm{POR}=37,242)$. Risiko keamanan pangan atau pemberian makan yang tidak baik berisiko 37 kali pada balitanya menderita stunting bila dibandingkan dengan balita yang memiliki keamanan pangan atau pola pemberian makan baik.

\section{UCAPAN TERIMA KASIH}

Peneliti mengucapkan terima kasih kepada Dinas Kesehatan Kabupaten Wawo atas ijin yang diberikan untuk melaksanakan penelitian serta seluruh responden yang terlibat pada penelitian ini.

\section{DAFTAR PUSTAKA}

1. Adair, L.S., et al., Associations of linear growth and relative weight gain during early life with adult health and human capital in countries of low and middle income: findings from five birth cohort studies. Lancet, 2013. 382(9891): p. 525-534.

2. Stulp, G., et al., Human Height Is Positively Related to Interpersonal Dominance in Dyadic Interactions. Plos One, 2015. 10(2): p. 1-18.

3. Black, R.E., et al., Maternal and child undernutrition: global and regional exposures and health consequences. The Lancet, 2008. 371(9608): p. 243-260.

4. Collaboration, E.R.F., Adult height and the risk of cause-specific death and vascular morbidity in 1 million people: individual participant meta-analysis. International Journal of Epidemiology, 2012. 41(5): p. 1419-1433.

5. Green, J., et al., Height and cancer incidence in the Million Women Study: prospective cohort, and meta-analysis of prospective studies of height and total cancer risk. The Lancet Oncology. 12(8): p. 785-794.

6. Nelson, C.P., et al., Genetically Determined Height and Coronary Artery Disease. New England Journal of Medicine, 2015. 372(17): p. 1608-1618.

7. Paajanen, T.A., et al., Short stature is associated with coronary heart disease: a systematic review of the literature and a meta-analysis. European Heart Journal, 2010. 31(14): p. 1674-1676.

8. Semba, R.D., et al., Effect of parental formal education on risk of child stunting in Indonesia and Bangladesh : a cross-sectional study. The Lancet, 2008. 371: p. 322-328.

9. Vonaesch, P., et al., Factors associated with stunting in healthy children aged 5 years and less living in Bangui (RCA). Plos One, 2017. 12(8): p. 1-17.

10. Davies, N.M., et al., The effects of height and BMI on prostate cancer incidence and mortality: a Mendelian randomization study in 20,848 cases and 20,214 controls from the PRACTICAL 
consortium. Cancer Causes \& Control, 2015. 26(11): p. 1603-1616.

11. Zhang, B., et al., Height and Breast Cancer Risk: Evidence From Prospective Studies and Mendelian Randomization. JNCI: Journal of the National Cancer Institute, 2015. 107(11): p. 1-17.

12. Child Health Epidemiology Reference Group Small-for-GestationalAge/Preterm Birth Working, G., Short Maternal Stature Increases Risk of Small-for-Gestational-Age and Preterm Births in Low- and Middle-Income Countries: Individual Participant Data Meta-Analysis and Population Attributable Fraction. The Journal of Nutrition, 2015. 145(11): p. 2542-2550.

13. Victora, C.G., et al., Worldwide Timing of Growth Faltering: Revisiting Implications for Interventions. Pediatrics, 2010. 125(3): p. e473-e480.

14. Trihono., et al., Pendek (Stunting) di Indonesia Masalah dan Solusinya. Balitbangkes, 2015. p. 89-90.

15. Chirande L, Charwe D, Mbwana $\mathrm{H}, \mathrm{Victor} \mathrm{R}$, Kimboka S, Issaka Ai, Et Al.Determinants of Stunting And SevereStunting Among Under-Fives InTanzania: Evidence From The 2010 Cross-Sectional Household Survey.Bmc Pediatrics. 2015;15(165):13.

16. Kusumawati E, Rahardjo S, Sari Hp.Model Pengendalian Faktor RisikoStunting Pada Anak Usia Di BawahTiga Tahun. Jurnal KesehatanMasyarakat Nasional. 2015;9(3):8.

17. Anisa P. Faktor-Faktor Yang Berhubungan Dengan KejadianStunting Pada Balita 25-60 Bulan DiKelurahan Kalibaru Depok Tahun2012. Depok: Universitas Indonesia;2012.

18. Oktarina Z, Sudiarti T. Faktor RisikoStunting Pada Balita (24-59
Bulan) Di Sumatera. Jurnal Gizi Dan Pangan.2013;8(3):6. 